\title{
The Location Choice of Foreign Direct Investment and Economic Development in Africa
}

\author{
Abdisalan Salad Warsame ${ }^{1}$ \\ ${ }^{1}$ The 7 Institute for Research and Development, Mogadishu, Somalia \\ Correspondence: Abdisalan Warsame, The 7 Institute for Research and Development Mogadishu, Somalia. \\ E-mail: awarsame@snu.edu.so
}

Received: June 21, 2021

Accepted: September 2, 2021

Online Published: September 5, 2021

doi:10.5539/ijef.v13n10p69

URL: https://doi.org/10.5539/ijef.v13n10p69

\begin{abstract}
Foreign Direct Investment (FDI) inflow to Africa has unevenly distributed investment location choices of multinational enterprises because of some exogenous economic factors associated with the locations, which vary across countries in Africa. The data used in the paper comes from Financial Times, World Bank, African Development Bank. This paper investigated what determines the location choice of FDI inflow to Africa using data on 3,768 firms from 88 countries making location choices in 54 African countries using a multicategory logistic regression. The findings show that: (1) the natural resource seeking enterprises invest more in landlocked countries relative to manufacturing and tertiary sector; (2) the natural resource seeking firms are less concerned about local market size and location's economic condition comparing to manufacturing and service industries; (3) despite the accusation against the multinational enterprises (MNEs) for exploiting Africa's natural resources, most of the MNEs choose locations with a large market size and better economic development; (4) the MNEs from developed economies prefer the location with a large market size and a better-developed economy comparing to those from the developing economies.
\end{abstract}

Keywords: FDI, location choice, multinational enterprises, economic development

\section{Introduction}

Recently, Africa receives billions of US dollars investment inflow annually that improves many aspects of economic conditions in the continent. Basically, multinational enterprises (MNEs) are neither humanitarian organizations nor their investment locations are randomly selected but explicitly determined by the economic factors associated with the locations that show sustainable profitability for the firm. The firm's location choice for investment is one of the most important decisions top managers make because location influences the firm's profitability while relocating is too costly. This paper addresses the unevenly distributed investment location choices of multinational enterprises due to some exogenous economic factors associated with the locations, which vary across countries in Africa.

This paper empirically attempts to answer the question of what are the determinants of MNEs' location choices in Africa. To do so, African countries were classified according to their natural resource abundance, market size, and economic development level. Note that, every African country has some type of natural minerals and it is impossible to classify Africa as a location with and without natural resources. To overcome this challenge, the study further categorized African countries according to their income level and market size; landlocked countries versus countries with access to the sea. It further classified the top 20 Oil \& Natural Gas producing countries and other countries. The researcher did that because these main assets could be used as a proxy for strategic assets and economic development.

This paper also categorizes industrial sectors into manufacturing, natural resource, and tertiary sector according to the "North American Industry Classification System" (NAICS) 2007. Due to some differences between African firms and non-African firms in nature, the location choice data used for this paper is exclusively Non-African MNEs, the MNEs come from other continents rather than Africa.

Then, the study shows that the location choice of MNEs varies across Africa due to the firm's characteristics and specific-location attributes. It reveals that manufacturing and service providing MNEs are less likely to invest in landlocked countries relative to natural resource seeking MNEs. The study also discovers that MNEs from 
developing economies are more likely to choose a location with small-medium market size and low-middle-income compared to MNEs from developed economies. With these findings, this study makes an important contribution to existing location choice literature. The study shows that, landlocked location is more likely to attract natural resource seeking firms than the manufacturing and service sectors relative to the location with sea access.

\section{Literature Review and Hypothesis}

Recently, Foreign Direct Investments (FDI) Inflow to Africa has remarkably increased; it is propelled by improving the economic condition and increasing natural resources production in Africa. Generally, firms go abroad and invest in an optimal site to maximize profits, and therefore, deciding a certain location for a firm is one of most critical decisions that executives of MNEs reach because location has real effects on the profitability and overall performance, while its relocation is costly (Bartik, 1985; Wei \& Liu, 2001; Li \& Park, 2006; Duanmu, 2010). The heterogeneities among both the MNEs and sectors influence their responsiveness to location-level factors. The location choice of MNEs from the developing economies differs from those of the developed world especially strategic asset seeking MNEs. According to (Yoo \& Reimann 2017; Sutherland, Anderson, \& Hua 2020), MNEs from developing economies invest in the location with strong knowledge-based assets and weak intellectual property protection while the weak intellectual property protection location deters the MNEs from the developed economies. The MNEs prefer investing in the location with a familiar culture with good economic institutions (Du, Lu, \& Tao 2012). FDI inflow to Sub-Sahara countries depends on trade openness, natural resource endowment, and the level of the market size (Rjoub et al., 2017).

The location choice of different industries and firms may differ due to their specific-inherent attributes. Basically, multinational enterprises (MNEs) are profit-oriented where the investment locations are not randomly selected but determined by the observable economic factors associated with the locations that lead to sustainable profitability for the firm. The hypothesis of this chapter was developed within the literature review. This examines the determinants of location choice of FDI projects in Africa, whether multinational enterprises (MNEs) are seeking markets, strategic assets, efficiency or/and natural resources. Further, there are systematically unproven allegations against non-African firms for exploiting natural resources, this is worth to be empirically investigated. An increasing FDI inflow to Africa has been significant, but yet it is scientifically unclear on what determines the location choices of foreign companies investing in Africa, and this study examines that phenomenon.

The location choice hypothesis is basically either of demand-oriented location or supply-oriented location. MNE's location choice is generally made based on exogenous economic factors that are associated with the host country (Dunning, 1981; Brainard, 1997; Carr, Markusen, \& Maskus, 2001; Blonigen, Davies, \& Head, 2003). The firm's location choice is determined by both inherent-characteristics and strategy. Therefore, the MNEs engaging in diverse industries consider different observable economic factors associated with locations. Similarly, these differences of location attributes will also influence the MNE's risk-taking appetite, performance, and economic impacts.

Broadly speaking, a firm can be either of demand-oriented or supply-oriented, Dunning (1973). Demand-oriented firms seek market while supply oriented ones look for factors of production (e.g., raw materials, labor and distribution strategy). Multiple factors may induce firms to go abroad to invest, some firms may go abroad due to saturated or/and unbearable competition at-home market, while other firms do that to avoid high corporate taxes. Some firms think a way to invest their income before the calendar year ends for tax avoidance strategy, so if there is no viable business opportunity at home country, then they may go to a foreign country that they can earn profits (Note 1).

\subsection{Market Seeking}

This theory is applied to a firm that enters foreign soil for business opportunities. Widely applied influential factors include market size when it comes to location choice. Previous empirical research showed that large market size has a positive impact on FDI inflows and attracts more FDI (Blomstrom \& Lipsey, 1991; Estrin, 2004; Na \& Lightfoot, 2006; Lee et al., 2008; Kang \& Jiang, 2010). The market size of the host country enables multinational companies to achieve a cost-effectiveness strategy through an economy of scales of domestic productions, (Venables, 1999; Braunerhjelm \& Svenson, 1996). Chinese Firms go out of China for market-seeking after facing cut-throat competition pressure at home (Deng, 2004; Buckley et al., 2007-8). In location choice, MNEs market-seeking prefer investing in developed economies because developing economies are associated with lower income per capita (Urata \& Kawai, 2000).

On the Contrary, Market seeking FDI opt for developing economies for potential rapid growth and less barriers of 
entry (Lin, 2010). Precisely: Hypothesis (H1), location with large market size increases the likelihood of being selected as an investment site, ceteris paribus. Large market size is probably a good location for MNEs qualitatively and quantitatively compared to a small one. Qualitatively, large size markets are a fiercely competitive environment that enhances the market quality and legal framework. Quantitatively, big market size enables MNEs to produce large-scale products (economies of scale) that might reduce the unit cost of production (Venables, 1999; Braunerhjelm \& Svenson, 1996). Such market places, most probably only giant and technological advanced MNEs dare to enter it and exercise the already internalized advantages.

\subsection{Strategic Asset Seeking}

Other location-specific attributes of location Choices include agglomeration economy, skilled workforces and good infrastructures (He, 2001; Na \& Lightfoot, 2006; Marti, Alguacil, \& Orts, 2015; Blanc-Brude et al., 2017): Location Attribute factors, agglomeration has positively correlated with FDI (Coughlin et al.,1991, Wheeler \& Moody, 1992; Braunerhjelm \& Svensson, 1996; Belkhodja1, 2016): and quality of human capital (He, 2001): Intellectual property protection as major location determinants (Wu, 2000; Javorcik, 2004; Belkhodja1, 2016): agglomeration has stronger impact on high-tech economies than in low-tech countries (Yao, Wang, Zhang, \& Ou, 2016). Skilled labor availability in China attracts high-tech US Firms ( $\mathrm{Du}, \mathrm{Lu}, \&$ Tao, 2007). Chinese firms with "stronger ownership advantages" prefer to invest in more developed than less developed regions" (Duanmu, 2012). Formally: Hypothesis (H2), a country with a better-developed economy upsurges the likelihood of being selected as an investment location by industrialized economies relative to developing economy.

This happens because MNEs from developed economies are adapted to industrialized markets and their products comparably, are of better quality than those from developing countries. This means they can be more expensive and mainly buyers from high-income countries can buy from them. The MNEs from the industrialized countries invest in a location with quality labor, good infrastructure and functioning economic institutions. Conversely, MNEs from the developing world produce lower quality products at a lower cost and sell at a cheaper price in other developing countries. Since these MNEs come from a developing economy, they can easily adapt to developing a business environment. The cost of production in high-income countries is higher than those in low-income countries. Therefore, the location choice of the industrialized economy qualitatively differs from those from the developing economy.

\subsection{Efficiency Seeking}

On the other hand, supply-oriented location happens when the multinational firms seek cheaper factors of production (e.g., raw materials, labor and distribution strategy), Dunning (1973). Firm location choice in cities shows that production inputs influence the firm's location choice in China and India (Sridhar \& Wan, 2010). Another study found that the location choices of Chinese companies have a positive relation to the economic growth of destination countries (Kang \& Jiang, 2010). Okafora, Piesseb, and Webster (2015) show that FDI inflow to Sub-Saharan African countries is market seeking, not resource seeking. Location choice shows differences in sub-regional investments: MNEs seeking efficiency invest in the South and East part of Africa, while both market and efficiency seeking FDI locate themselves to invest in Central and west of Africa. Most influential factors of FDI attraction in SSA are political-economic stability and factor of production (Bartels, Napolitano, Nicola, \& Tissi, 2014).

Chinese regions' wage differentials affect the location choice of labor-intensive industry (Liu, Lovely, \& Ondrich, 2010). Formally: Hypothesis (H3), The location with cheaper inputs increases the country's likelihood of being selected as an investment location, ceteris paribus. After constructing a highway that links one country to another and big seaports, it has made many untouched marketplaces at glance to be accessible. Many countries in Africa are landlocked that deterred FDI inflow in the past but recently, there is no more a barrier. Countries with access to sea consider their neighboring landlocked nations as a good source of revenue constructing highways and big seaports that can handle thousands of containers. Therefore, efficiency-seeking MNEs consider a location with a lower cost of a factor of production even in landlocked countries. Uganda, Ethiopia, and Rwanda are a good example.

\subsection{Natural Resources Seeking}

Choosing a foreign production location could also be a result of natural resources seeking motives. One of the compelling arguments of Dunning (1993) was that some firms have a natural resource-seeking ambition to gain and assure continuously streaming sources of the natural resources. Similarly, the scarce natural resource exploitations are important via "equity-based control", Casson and Buckley (1976). This theory of natural resource exploitations is widely applied to natural resource-abundant developing countries through corporatocracy and economic hitman agents supported by their governments, Perkins (2004). A study about 62 FDI hosting countries, 
reveal that natural resource-abundant developing countries attract more FDI, the natural resource endowments can compensate the institutional constraints between two countries (host and home) Kang (2018). Chinese outward FDI seeks natural resource-abundant countries (Deng, 2004; Kang, 2018).

There is a high positive correlation between location choice and natural resources richness of destination country (Kang \& Jiang, 2010). Chinese MNEs invest in locations with good institutional standards, developing with more natural resource endowment as well as high return and cheaper factors of production (Yang et al., 2018). FDI flow into locations with non-renewable natural resources (Faeth, 2009; Chanegriha et al., 2016; Teixeira, Forte, \& Assuncao, 2017): Natural resource endowment attributes, most specifically, non-renewable natural resources and human capital (Asiedu, 2006; Cleeve, 2008).

Hypothesis (H4), being a landlocked country with natural minerals increases the chances of being chosen by natural resource seeking MNEs comparing to non-natural resource firms. Firms from the industrialized world, struggle for a cheap and continual supply of natural resources in developing nations (John, 1993). State-owned firms are attracted to the location with huge natural resource endowment and politically unstable environment but private firms are just market seekers (Ramasamy, Yeung, \& Laforet, 2012). According to the investment development path (IDP) theory, argued that the "country's economic development level" determines the FDI inflow and the type of FDI inflow. The theory underlines five development stages, (Dunning, 1981; Dunning \& Narula, 1996; Tolentino, 1987), but stage one applies to this study that merely explains the developing world. This stage is associated with developing countries where most of the MNEs don't invest in the entry-level country, but only a few natural resources seeking firms will exploit them. Countries at stage one, are associated with poor conventional FDI attraction factors (poor economic and institution condition). This stage explicitly explains the factors that attract conventional FDI and Corporatocracy FDI; the two are completely different. Corporatocracy FDI cares less about the economic development of the host country as long as there is natural resource abundance.

Generally, African firms investing in Africa are characteristically different from non-African MNEs in terms of social connection to the local community and distance. In other words, location choices of foreign firms would be qualitatively different from the location choices of African firms, while African investors have easier access to market and information than foreign investors. Further, foreign firms are mostly from industrialized and politically influential countries, so such firms have better technology, economic development (capital muscle) and competitive advantages than African firms. All of these (absolute and comparative advantage differences) create location choices disparities between African firms and foreign firms. These disparities will also cause their differences in investments and the industrial concentration of the two parties. Therefore, this study employs only the data of non-African firms invested in Africa. The researcher hypothesized a sample of 3,768 MNEs from 88 countries investing in 54 African countries using multicategory logistic regression that allows the choice of more than two categories, and similar to conditional logistic model, it applies the maximum likelihood of estimation for evaluating the probability of categorical association. The simplest assumption is that the choice of one category should not have a link to the choice of another category (independences among the dependents).

\section{Classification of Locations}

The sub-regions of Africa have dichotomous characteristics, which makes the sub-regional categorization inappropriate because the countries under one region have different levels of development, market size, strategic assets, and other characteristics that differ from other countries in the same sub-region. Apparently, every African country has some type of natural minerals implying that any classification of African countries as a location with natural resources and location without natural resources will produce misleading conclusion, unless further conditions apply. Therefore, African countries were classified according to their income level, market size, and strategic assets. For location specific-attributes, the following were considered; economic development (measured by income per capita) and market size (measured by GDP) using data from IMF (WEO, 2017). Further, for robustness checks and analysis of location-specific characteristics on investment locations, locations were divided into landlocked countries and countries that have access to the sea as well as the top 20 Oil and Gas producing countries versus other countries in the continent. This is a research work where one can conduct a research subjectively. Therefore, this market classification is a subjective work.

The study classifies the market size as a large, middle and small size using GDP as a proxy for market size. Firstly, Countries with the gross domestic product (GDP) that is more than one hundred billion (100 billion) US dollars are considered as big market size. Secondly, Countries with GDP in between average and one hundred billion are also grouped as medium market size (average GDP of Africa is 40.5 billion in 2017). And thirdly, the countries with GDP below average were included as small market size countries. The location's market size affects the firm's economies of scale and large market size enables the firms to produce more at/by decreasing the cost per unit. Due 
to poor economic conditions and badly divided countries by the colonists, most of the African countries have a tinny market size. 73.6 percent of countries in Africa have small market sizes, 15.1 percent of the countries have middle-market size, and countries with big market sizes are 11.3 percent. Population size was also applied for redefining the market size. About 13 percent of African countries have large population size, 20.4 percent have medium, and 66.7 percent have small population size. The average size of these countries is 91 million, 31 million, and 7 million (see Table 1). If one looks at GDP size and population size of the countries, they can easily realize both variables are closely related, so it can properly redefine the market size.

The country's income per capita is used as an economic development indicator. Even though per capita GDP is widely used for poverty and development studies, it has a great shortcoming because it does not consider so many important factors relevant to poverty and economic development, including income disparity, growth shares, and institution quality. Nevertheless, the income level is a good indicator of location quality because it indicates the purchasing power of local people. Income levels are grouped into high, middle and low income. The Countries with an above-average income per capita $(\$ 2,500)$ are considered as high-income countries and those with income in between average and one thousand (\$1000) US dollars are counted as middle-income countries. Lastly, countries with below one thousand US Dollars of income per capita are considered as low-income countries. Additionally, 42.4 percent of countries in Africa go in low-income levels, while high- income countries are 27.9 percent and middle-income nations are 29.7 percent. This means nearly half of African countries are at the low-income level.

In the further analysis, the study arranged the countries like countries without access to the sea (landlocked) and countries with access to the sea. And also, it classified the locations such as the top 20 Oil and Gas producing countries and non-top-20 Oil \& Gas producing countries. These two more classifications of African countries were applied for robustness checks that enabled the study to draw better inferences. The study also analyzed location choice differences in Africa between developing and developed countries.

\section{Data}

This paper uses countries as location and the number of countries used are 54 African countries. The source of this data is Financial Times; it is the most comprehensive online database of cross-border Greenfield investments available, covering all countries and sectors worldwide. The number of firms was 3,768 from 88 different countries investing in across 54 African countries making 7,175 location choices. This data is a firm-level that provides the firm's characteristics (basic information including, home country, host country, investment amount and number of jobs created) covering the period of January 2003 to June 2017. The data is collected in real-time as announced by a company and provided as a daily e-mail newswire and live updates online. Before being published, data goes through a rigorous quality control process at the end of each month. The data of population, gross domestic products (GDP), GDP per capita income, and control variables (Governance indicators) come from World Development Indicators, World Bank. Industrial classification was classified according to its cluster, sector, sub-sector and business activity, based on North American Industry Classification System (NAICS) 2007. The location choices of African and None-African MNEs are incomparable due to some inherent characteristics, which have been explained at the end of the literature. Therefore, this chapter exclusively applies data of none-African multinational enterprises.

\section{Empirical Estimation}

This paper analyzes the determinants of MNEs' location choice in Africa using multicategory logistic regression that can handle more than two categorical choices and firm-level data from Financial Times (2003 to June 2017). To do so, African countries were classified according to their natural resource abundance, market size, and economic development level. The Caveats, the study found that every African country has some type of natural minerals, so it is impossible to classify African countries as a location with and location without natural resources.

To find a solution for those challenges, the study categorizes African countries according to their levels of income and market size, landlocked countries and countries with access to the sea. The researcher also classified the top 20 oil and natural gas producing countries and other countries. This was done because these main assets (Oil and Gas) could be used as a proxy for strategic assets and economic development. The researcher also categorized industrial sectors into manufacturing, natural resource, and tertiary sector according to the "North American Industry Classification System" (NAICS, 2007). Moreover, the study used the country of origin, industrial sector, and subsector as proxy for a firm's location choice. The paper also analyzed the top 10 locations chosen by the FDI Inflow to Africa and further explains the common and different factors associated with these top ten countries. The data used for this chapter is none-African MNEs (MNEs from outside the 
Africa continent).

The other reason for classifying the African countries into the top twenty-oil and gas producing countries versus none-top 20 countries in Africa was for robustness checks. For better outcomes, it was necessary to find other ways to redefine the locations, similar to the classification of African countries as landlocked and non-landlocked for better estimation of the results. Therefore, the study analyzed how these main assets (Oil and Gas) influence location choice.

\section{Research Methodology}

The investment location choice is not made based on random selection; it depends on the location's expected return. The function of the firm's profitability is a function of exogenous factors associate with the location (Nachum, Zaheer and Gross, 2008).

$$
y_{i j}=X_{i j} \beta+\varepsilon_{i j}
$$

where $y_{i j}$ represents the dependent variable, the profit of firm $i$ invests in location $j$ and $X$ is a vector variable that represents the exogenous factors associated with the host country. The $\varepsilon_{i j}$ is an error term that is associated with the firm's location choice.

\subsection{Model Specification}

The basic empirical model is:

$$
\text { choice }_{j t}=\alpha_{0}+\sum \beta_{1} g d p_{j t}+\sum \beta_{2} \text { inc }_{j t}+\sum \beta_{3} \text { asst }_{j t}+\sum \beta_{4} \text { port }_{j t}+\sum \gamma_{5} W G I_{j t}+\varepsilon_{j t}
$$

The dependent variable choice $_{j t}$ (incoming foreign firms) stands for location choice of firm investing in location $\mathrm{j}$ at time $t$. The $g d p_{j t}$ is market size (independent) that might influence the location choice of foreign firms for investment. Market seeking FDI inflow has higher propensity to be attracted by the location with large market size than small market size locations keeping other things equal. This market size is measured by the size of gross domestic products (GDP). The GDP is one of the most widely used indicators for economic conditions because it takes into account the nation's consumption and investments. The inc $_{j t}$ is income per capita of African countries used as economic development of the location. The asst $t_{j t}$ is top 20 gas and oil producing countries and it is used as locations quality in term of living standard and market size. The oil and gas production may improve the living income and contribute a significant portion to the nation's GDP. The port ${ }_{j t}$ is strategic assets of the locations and represents the location with access to the sea and location without access to the sea. Location's access to the sea has profound positive impact on the country's development and attractiveness.

The $W G I_{j t}$ are control variables that have impact on location quality and attractiveness. This control variable is governance indicators that capture the political stability and regulation/law quality of the location. The control variables $W G I_{j t}$ are the six worldwide governance indicators and capture political risk, market access, economic institutions, and economic crimes that affect location quality. The Worldwide Governance Indicators (WGI) is one of the indicators used to analyze social integrity and governance quality. This study used only four out of the six governance indicators and each indicator has specific effects on location. The four governance indicators used are Government Effectiveness, Political Stability, and Absence of Violence/Terrorism, Regulatory Quality, and Control of Corruption. Government effectiveness captures the effects of institution integrity and market access.

On the other hand, Political Stability and Absence of Violence/Terrorism deal with political risk and environmental uncertainty. Regulatory Quality handles the government's policy formulation and implementation that promotes the private sector. Control of Corruption captures the use of power for personal gains and other economic crimes. These indicators influence the location choice because they cover general location attractiveness and social integrity. The location with high non-negative governance indicators may enjoy more FDI inflow than the location with low/negative good governance indicators. These governance indicators are applied to the level of location quality, institution, social integrity, and governance. Governance indicator data is lagged one year because the MNEs analyze the location before investing. The error term $\varepsilon_{j t}$ stands for the unobservable factors associated with the location. Location means country throughout this chapter.

\section{Empirical Results}

This section demonstrates and explains the empirical results from MNEs' location choice studies using firm-level data from the Financial Times (2003-June 2017). The paper employs MNEs' location choice basing on income levels, market size, and natural resources by sectors. Table 1 is summary statistics that provide basic description of the variables used in the study. The seaport variable denotes whether the location has access to the sea or has no access to the sea and it's a strategic asset of the location. The top oil and gas producing locations 
are great assets that generate income, improving the market and living conditions of the people in the location. To redefine the dependent variable location, the researcher classified the locations as a location without access to the sea and location with access to the sea. For further redefining, locations were categorized into the top 20 Oil and Gas producing locations and other countries. In this chapter, location represents country.

As the table below indicates, Africa has a poor record of governance indicators. The high negative governance indicators imply poor public administration and business environment and vice versa. Corruption and political stability have the largest negative values in the below table 1, which indicates these two factors; high corruption and political instability rates in Africa that might deter investment inflow. Population size is used to redefine the market size. For more explanations of governance indicators, see the definitions of control variables in the appendix.

Table 1. Summary statistics

\begin{tabular}{|c|c|c|c|}
\hline VARIABLE & $\mathrm{N}$ & MEAN & $\mathrm{SD}$ \\
\hline \multicolumn{4}{|l|}{ Independent Variables } \\
\hline \multicolumn{4}{|l|}{ Market Size (GDP in $\$$ billion) } \\
\hline Large Size $(11.3 \%)$ & 90 & 198.63 & 126.11 \\
\hline Medium Size (15.1\%) & 120 & 35.68 & 16.45 \\
\hline Small Size $(73.6 \%)$ & 584 & 8.35 & 9.48 \\
\hline \multicolumn{4}{|l|}{ Income Level (\$ thousands) } \\
\hline Upper Income (27.9\%) & 225 & $6,464.76$ & $5,136.43$ \\
\hline Middle Income (29.7\%) & 240 & $1,398.60$ & 685.01 \\
\hline Low Income (42.4) & 342 & 539.52 & 234.92 \\
\hline Sea Ports & 7,175 & 1.9 & 0.29 \\
\hline Top 20 Oil \& Gas Producing & 7,175 & 1.26 & 0.44 \\
\hline \multicolumn{4}{|l|}{ Population Size (Million) } \\
\hline Large Size (13\%) & 7 & $9.10 \mathrm{e}+07$ & $4.91 \mathrm{e}+07$ \\
\hline Medium Size (20.4\%) & 11 & $3.12 \mathrm{e}+07$ & $7,354,914$ \\
\hline Small Size $(66.7 \%)$ & 36 & $7,294,874$ & $6,192,170$ \\
\hline \multicolumn{4}{|l|}{ Control Variables } \\
\hline Corruption Control (CC) & 7,175 & -0.51 & 0.51 \\
\hline Government Effectiveness (GE) & 7,175 & -0.28 & 0.58 \\
\hline Political Stability (PS) & 7,175 & -0.48 & 0.71 \\
\hline Regulatory Quality (RQ) & 7,175 & -0.37 & 0.66 \\
\hline \multicolumn{4}{|l|}{ Dependent Variables } \\
\hline choice $_{j t}$ (firm's location choice) & 3,768 & 2237.76 & 1324.54 \\
\hline Source countries & 88 & 54.63 & 27.22 \\
\hline
\end{tabular}

Note. The percentages of market size and income are given in Table 1. As shown in this table 1, the percentages in the bracket indicate the market size and income level of different locations. This study uses only four variables out of the six WGI variables. Industry is the firm's economic sector (the sector firm invests in). It is used as proxy for investing firm. This provides a comprehensive inference about the difference of sector's location choices.

Market size $(G D P)$ is an explanatory variable (measured by the GDP of countries). It is divided into the large market size, medium market size, and small market size. The researcher subjectively classifies the market size as a large, middle, and small size using GDP as a proxy for market size. Firstly, Countries with the gross domestic product (GDP) that is more than one hundred billion (100 billion) US dollars are considered as big market size. Secondly, Countries with GDP in between average and one hundred billion are also grouped as medium market size (average GDP of Africa is 40.5 billion in 2017). And thirdly, the countries with GDP below average were included as small market size countries. About $11.3 \%$ of African countries have large market size, $15.1 \%$ are medium market size, and $73.6 \%$ are small market size countries.

Income level is an independent variable used as a development indicator for the location because per capita GDP is widely used for poverty and development studies. Income levels were grouped into high, middle, and low income. The Countries with an above-average income per capita $(\$ 2,500)$ are considered as high-income countries. Those with income in between average and one thousand (\$1000) US dollars are counted as middle-income countries. Lastly, countries with below one thousand US Dollars of income per capita were considered as low-income countries. Additionally, 42.4 percent of countries in Africa go in low-income levels, 
while high-income countries are 27.9 percent, and middle-income countries are 29.7 percent. It implies that nearly half of African countries are at the low-income.

Seaport is an independent variable and indicates the location's accessibility to the seashores. The study divides African countries into countries with access to the sea and countries without access to the sea (landlocked countries and countries with access to the sea). In this chapter, location means country. Interestingly, all landlocked countries in Africa are low and middle income, except only two countries. Around $27.9 \%$ are high-income countries, $29.7 \%$ middle income, and $42.4 \%$ low income in Africa. In Africa, countries with a large market size are very few compared to countries with small and medium-size markets. Besides that, all landlocked countries are counted as either small or medium market size. In the empirical results, countries with access to the seashores were used as a referent group.

The top 20 Oil and Gas producers are African countries, which are the top 20 Oil and Gas producers. The study also classified the locations such as the top 20 Oil and Gas producing countries and non-top-20 Oil \& Gas producing countries. The researcher believes that these top 20 Oil and Gas producing countries have income-generating assets that contribute a significant amount to the GDP and improve the economic infrastructures. As shown in Table A1 in Appendix A, the top 20 Oil and Gas producing countries and market size are highly correlated. The referent variable is top 20 Oil and Gas producers in the result. Population size is an independent variable used to redefine the market for robustness checks. Around 13\% of African countries are big market size, $20.4 \%$ are medium market size, and about $66.7 \%$ are small market size countries using population size as a measuring unit. This population size classification shows that the population size and market size have a close relationship.

The dependent variable is the firm's location choice for investment (y). In other words, they are the ones coming from outside Africa and investing in African countries. It is a continuous variable where one firm may invest in many countries. Therefore, incoming MNE's location choice for investment depends on exogenous variables associated with the location (the host countries). The Source countries are foreign countries in which FDI originated. The source countries are the home countries of MNEs used as the dependent variable for redefining the explained variable, particularly for five fund origin countries (China, US, France, India, and the UK) used for analyzing the location choice similarity and dissimilarity between the developing and developed countries.

The multinomial logistic regression has a referent group and coefficients (outcomes). Therefore, the standard interpretation of the multinomial logistic regression results is that the estimates are interpreted relative to the referent level (base outcome) keeping other predictor variables constant. Under the market size, there are two predictor variables which were translated relative to the referent group. For instance, the referent group is a medium market size. The following Table 2 presents the location choice of foreign firms that engage in various sectors and how respective economic sectors determine their location choice for investment. The study classifies the industrial sectors as three main economic sectors (manufacturing, natural resource, and tertiary sector) in accordance with "North American Industry Classification System" (NAICS, 2007). It is intended to use the sector as a proxy for firm's location because the firm's sector type determines its location choice as the following empirical results reveal. The natural resource seeking enterprises select the natural-resources abundant location regardless of the market size and development level of the location. Poor and tinny market size countries with natural resources abundance in Africa are most likely to be institutionally weak.

Table 2 shows that the firm's location choice is determined by its intrinsic attributes. Column1 represents manufacturing firms and (2) represents natural resource seeking firms. The referent variable for the sectors is the tertiary sector and for market size is the medium market. Therefore, the standard interpretation of the coefficient is comparing the outcome to the referent group. As shown in Table 2, for market size prospects, the natural resource seeking firms invest more in small market sizes than the large market size. The natural resource seeking companies are also less sensitive to environmental uncertainty comparing to manufacturing and tertiary sectors as documented in the literature. Under column1 (manufacturing MNEs) invest in large-medium market size than small market size. In other words, manufacturing MNEs preference is 0.41 units lower in small markets relative to medium market size (this implies manufacturing firms prefer 0.41 units higher in the medium-size market relative to small market size). The large market size preference of manufacturing MNEs relative to medium size, indicate inconsistent and negligible differences in the result, implying that manufacturing MNEs prefer medium-large market size in Africa. To redefine market size, the study used population size for robustness checks (Table 5). On the other hand, column2 (natural resource seeking MNEs) preference to large market size is 0.242 smaller than medium size and 0.841 units higher in small market size relative to medium market size (this means natural resource seeking MNEs prefer 0.841 units more than small market size and 0.242 lesser in large market size comparing to medium market size). 
Table 2. Location choice of Non-African enterprises by sector (2003-June 2017)

\begin{tabular}{|c|c|c|c|c|c|c|c|c|}
\hline \multirow[b]{2}{*}{ Independent Variable } & \multicolumn{8}{|c|}{ Dependent Variables (Firm's location Choice) } \\
\hline & $(1)$ & $(2)$ & $(1)$ & (2) & $(1)$ & $(2)$ & $(1)$ & $(2)$ \\
\hline \multirow[t]{2}{*}{ Large Market } & -0.0166 & $-0.242 * *$ & -0.000238 & -0.156 & 0.0253 & $-0.246 * *$ & 0.00684 & $-0.232 * *$ \\
\hline & $(0.062)$ & $(0.098)$ & $(0.063)$ & $(0.1)$ & $(0.062)$ & $(0.099)$ & $(0.061)$ & $(0.098)$ \\
\hline \multirow[t]{2}{*}{ Small Market } & $-0.411 * * *$ & $0.814 * * *$ & $-0.411 * * *$ & $0.694 * * *$ & $-0.347 * * *$ & $0.901 * * *$ & $-0.418 * * *$ & $0.718 * * *$ \\
\hline & $(0.079)$ & $(0.099)$ & $(0.080)$ & $(0.101)$ & $(0.084)$ & $(0.106)$ & $(0.080)$ & $(0.1)$ \\
\hline \multirow[t]{2}{*}{ Low Income } & 0.0345 & $0.629 * * *$ & 0.0522 & $0.484 * * *$ & 0.0612 & $0.558 * * *$ & 0.0418 & $0.548 * * *$ \\
\hline & $(0.088)$ & $(0.106)$ & $(0.088)$ & $(0.106)$ & $(0.088)$ & $(0.105)$ & $(0.088)$ & $(0.105)$ \\
\hline \multirow[t]{2}{*}{ Upper Income } & 0.0679 & -0.157 & 0.0656 & 0.0901 & $0.251 * * *$ & $-0.425 * * *$ & $0.124^{*}$ & -0.059 \\
\hline & $(0.07)$ & $(0.1)$ & $(0.071)$ & $(0.098)$ & $(0.066)$ & $(0.091)$ & $(0.064)$ & $(0.091)$ \\
\hline \multirow[t]{2}{*}{ None Top 20 Gas \& Oil } & $-0.150^{* *}$ & $0.325 * * *$ & $-0.141 * *$ & $0.156^{*}$ & $-0.162 * * *$ & $0.379 * * *$ & $-0.164 * * *$ & $0.291 * * *$ \\
\hline & $(0.058)$ & $(0.077)$ & $(0.060)$ & $(0.080)$ & $(0.058)$ & $(0.077)$ & $(0.058)$ & $(0.078)$ \\
\hline \multirow[t]{2}{*}{ Landlocked Countries } & $0.229 * *$ & $0.701 * * *$ & $0.285^{* * *}$ & $0.436^{* * *}$ & $0.181 * *$ & $0.758 * * *$ & $0.219 * *$ & $0.548 * * *$ \\
\hline & $(0.09)$ & $(0.109)$ & $(0.093)$ & $(0.114)$ & $(0.090)$ & $(0.11)$ & $(0.091)$ & $(0.111)$ \\
\hline $\mathrm{CC}$ & Yes & Yes & & & & & & \\
\hline GE & & & Yes & Yes & & & & \\
\hline PS & & & & & Yes & Yes & & \\
\hline RQ & & & & & & & Yes & Yes \\
\hline \multirow[t]{2}{*}{ Constant } & $-0.206^{* * *}$ & $-1.650 * * *$ & $-0.252 * * *$ & $-1.651 * * *$ & $-0.319 * * *$ & $-1.578 * * *$ & $-0.269^{* * *}$ & $-1.649 * * *$ \\
\hline & $(0.059)$ & $(0.091)$ & $(0.054)$ & $(0.0844)$ & $(0.06)$ & $(0.089)$ & $(0.053)$ & $(0.082)$ \\
\hline Observations & 7,175 & 7,175 & 7,175 & 7,175 & 7,175 & 7,175 & 7,175 & 7,175 \\
\hline
\end{tabular}

Note. (1) = Manufacturing MNEs. (2) = Natural Resource MNEs. The referent group is medium market size (Note 2).

Non-top 20 Oil \& Gas is the countries which are not member of top 20 Oil and Gas producing countries. landlocked countries are the countries with no access to the sea. The six WGI are fairly correlated and therefore each variable was controlled at a time (Note 3 ). Standard errors in parentheses, $* * * \mathrm{p}<0.01, * * \mathrm{p}<0.05, * \mathrm{p}<0.1$.

The firms in the tertiary sector also invest in medium and large market size more than small markets according to the result in Table 2. Generally, the service sector is more development and market size location-oriented than natural resource seeking MNEs because the service sector is more knowledge-based and economic development. Service firms consider the market needs and location quality to provide the needed service. The result in Table 2 implies that manufacturing firms prefer more a large-medium market size location than a small market size location. Generally, the natural mineral production in Africa is for export and it just depends on the availability of the natural resource, not for local market size and economic condition. Many FDI projects invest in the natural resources sector in countries which are economically feeble and politically unstable. The least developed and tinny market countries have less to offer to attract more none- natural resource seeking FDI investments.

According to Table 2, the natural resource seeking MNEs are less concerned about location development level as long as a natural resource is available. Confirming the results shown in Table 2, the natural mineral seeking firms invest in low-income and middle-income location relative to high income location. This result indicates that the location-specific attribute of natural resource seeking companies is the availability of natural minerals. According to results in this Table, manufacturing MNEs relative to service MNEs is 0.0334 units higher for being in low-income relative to middle-income location while natural resource seeking MNEs relative to service MNEs is 0.629 units higher for being in low income comparing to middle-income location. Normally, the international investment norms in Africa are affiliation-based in terms of politics, colonial history, religious and economic cooperation that creates a deviation from the traditional FDI location choice. Manufacturing MNEs relative to service MNEs is 0.0679 units higher for being in upper-income relative to middle-income location while natural resource seeking MNEs relative to service MNEs is 0.157 units lower for being in upper income comparing to low-income location.

In Table 2 also presents how the top 20 Oil and natural Gas producing locations in Africa influence the MNEs' location choice. The well-known mineral reserves in Africa are driving forces behind some economies in the continent, contributing a large portion of GDP and other developments. About 30 percent of the top 20 Oil and gas producing countries are countries with large market size and 25 percent are countries with a medium market size. Furthermore, 45 percent of these countries are high-income countries and 30 percent are middle income. 
According to data, non-African MNEs invested 92.5 percent of the total natural resources in Africa over the last 14.5 years, which means African MNEs only got 7.5 shares of the natural resources. Further, about 75 percent of total observations went into these top 20 oil-producing countries. The top 20 Oil and Gas producing countries are measured by their per day production capacity and they are countries that produce 200 barrels or more per day. Moreover, 85 percent of these countries have access to seawater. The relationship between market size and top 20 Oil and gas producing location is above 70 percent.

On the other hand, there are two facts with non-top-20 Oil and Gas producing countries, (a) fourteen countries ( $87.5 \%$ of landlocked nations) are among them out of sixteen landlocked countries in Africa, and (b) there is no any country with large market size (GDP) among them. Further, around 84.6 percent are low-income countries and $82.5 \%$ are small market size countries.

This is why natural resource seeking MNEs invest in non-top 20 Oil and Gas producing countries comparing to manufacturing top 20 Oil and Gas producing countries. Manufacturing firms are concerned much about market size and economic development compared to the natural resource seeking firms. Manufacturing MNEs relative to service MNEs, is 0.150 units lower for being in non-top 20 Oil \& Gas producing locations relative to top-20 Oil \& Gas producing location while natural resource seeking MNEs relative to service MNEs is 0.325 units higher for being in non-top 20 Oil \& Gas producing location relative to top-20 Oil \& Gas producing location. As the results demonstrate manufacturing firms prefer large market size relative to small market size locations, all locations with big market size are also among top-20 Oil and Gas producing countries implying that these oil and gas productions contribute a significant portion to the national gross domestic product (GDP).

Besides that, the study also analyzed how location with access to the sea influences a firm's location decision across all industries. In Africa, there are 16 landlocked countries (32.65\% of all landlocked countries in the globe), but also about 30 percent of the African countries are landlocked. The findings from this study reveal that natural resource seeking companies invest more in landlocked countries than locations with access to the sea while service firms invest more in the location with access to the sea. The service and manufacturing MNEs invest in a location that has access to the sea more than the location that has no sea access. This indicates that service and manufacturing enterprises prefer a location with access to sea rather than no sea access countries. Location with easy access to the sea gives manufacturing companies a chance to import things or export their products to where they want, that lowers the cost of shipment.

Generally, the countries with easy access to the sea have a higher potentiality of economic development, but landlocked countries are constrained in many ways of development aspects. As documented in chapter three, information technology and communication infrastructures make countries with sea access attractive to international investors, technology has great potentiality. Service includes ICT infrastructure and the researcher shows that fiber optic internet comes to Africa through the sea from the Middle East and Europe. It has thus enhanced internet accessibility, speed, and availability that make Africa an attractive location. Also, in the tourism industry, countries without access to the sea may not be attractive to tourism compared to countries with access to the sea because the sea has natural beauties and other traditional economic benefits.

Besides being constrained by the lack of access to seawater, there are several other disadvantages associated with most of these countries including small market size, low income per capita, internal conflicts, long-time ruling dictator leaders and weak economic institutions. All of these disadvantages divert the FDI Inflow away from them. Thus, natural resource seeking MNEs take advantage of these desperate States for FDI inflow because these types of investments are less concerned about local economic conditions and market size.

The following Table 3 refines the market size of location using population size that confirms the robustness of the result in Table 2. After redefining the market size using population size, it indicates that the manufacturing firms (column 1) invest lower in medium-small population size locations than natural resources seeking (column 2) MNEs. Manufacturing MNEs prefer to invest in the location with large population size (big market size) than small-medium locations while natural resource seeking MNEs invest more in the location with a small population than manufacturing MNEs relative to tertiary MNEs. The implication of this result is that natural resource production is not for sale neither in the domestic market nor nearby neighboring markets, but it is intended for export to the other continents. Further, natural resource seeking MNEs get support and/or protection from their home country and the host country while they sometimes intervene in the political affairs in the host country to assure continuity of their natural resource production activities. Column1 is manufacturing firms and column (2) is a natural resource seeking firms. 
Table 3. Location choice of Non-African enterprises by sector (2003-June 2017)

\begin{tabular}{|c|c|c|c|c|c|c|c|c|}
\hline \multicolumn{3}{|c|}{ Independent Variable } & \multicolumn{5}{|c|}{ Dependent Variable (Firm's location Choice) } & \multirow[b]{2}{*}{ (2) } \\
\hline Population Size & $(1)$ & $(2)$ & $(1)$ & $(2)$ & $(1)$ & $(2)$ & $(1)$ & \\
\hline Large size & 0.0625 & -0.0158 & 0.0329 & 0.0455 & 0.0822 & -0.103 & 0.0509 & 0.0812 \\
\hline & $(0.058)$ & $(0.091)$ & $(0.06)$ & $(0.092)$ & $(0.057)$ & $(0.090)$ & $(0.060)$ & $(0.093)$ \\
\hline Small size & $\begin{array}{c}-0.215 * * * \\
(0.074)\end{array}$ & $\begin{array}{c}0.786 * * * \\
(0.092)\end{array}$ & $\begin{array}{c}-0.222 * * * * \\
(0.074)\end{array}$ & $\begin{array}{c}0.760 * * * \\
(0.093)\end{array}$ & $\begin{array}{c}-0.212 * * * \\
(0.075)\end{array}$ & $\begin{array}{c}0.834 * * * \\
(0.094)\end{array}$ & $\begin{array}{c}-0.207 * * * \\
(0.074)\end{array}$ & $\begin{array}{r}0.712 * * * \\
(0.093) \\
\end{array}$ \\
\hline $\mathrm{CC}$ & yes & yes & & & & & & \\
\hline GE & & & yes & yes & & & & \\
\hline PS & & & & & yes & yes & & \\
\hline RQ & & & & & & & yes & yes \\
\hline Constant & $\begin{array}{c}-0.226^{* * * *} \\
(0.041)\end{array}$ & $\begin{array}{c}-1.785^{* * * *} \\
(0.068)\end{array}$ & $\begin{array}{c}-0.242 * * * \\
(0.038)\end{array}$ & $\begin{array}{c}-1.711^{* * *} \\
(0.064)\end{array}$ & $\begin{array}{c}-0.244 * * * \\
(0.044)\end{array}$ & $\begin{array}{c}-1.747 * * * \\
(0.07)\end{array}$ & $\begin{array}{c}-0.246^{* * * *} \\
(0.038)\end{array}$ & $\begin{array}{c}-1.696^{* * * *} \\
(0.063)\end{array}$ \\
\hline Observations & 7,175 & 7,175 & 7,175 & 7,175 & 7,175 & 7,175 & 7,175 & 7,175 \\
\hline
\end{tabular}

(1) = Manufacturing MNEs. (2) = Natural Resource MNEs. Referent variables are tertiary and medium market size.

$\mathrm{CC}=$ Corruption Control, GE= Government Effectiveness, PS= Political Stability, and RQ= Regulatory Quality.

Significance level, $* * * \mathrm{p}<0.01, * * \mathrm{p}<0.05, * \mathrm{p}<0.1$.

Conversely, manufacturing MNEs often produce products for domestic and nearby markets. Large market/population size provides manufacturing and service MNEs opportunities for economies of scale. The scale of operation has cost advantages for MNEs. For instance, the large market shows a positive coefficient throughout column 1 in Table 3 while small market size shows a negative coefficient throughout column1, which means manufacturing MNEs prefer the large market size. On the other side, the large market size shows a negative coefficient throughout column2 in Table 3 while small market size shows positive coefficient throughout column2, which means natural resource seeking MNEs prefer small market size, which implies natural resource seeking MNEs don't bother about the domestic market size.

In Table 4 the study examines the location choices of investor countries (fund origin countries) showing that France, the United Kingdom, and the United States prefer to invest in big market size locations and high-income countries rather than small size markets and low-income countries comparing to India. On the other hand, India invests in small and medium-size markets and low- and middle-income locations relative to China. The reasons could be that the firms from the west have better internalization advantages and feel comfortable with the location with big market size and developed economy because they can get better legal framework and protection. The western countries have a better connection to African countries than India and China that dates back to the colonial period as well as their current political influences on Africa, in which MNEs might capitalize on it. The economic and political influence of China on Africa has substantially increased in recent years and many African leaders have a high propensity to Chinese relationships because of its political neutrality and its economic nature. MNEs from developed countries are less likely to invest in landlocked location comparing to MNEs from developing countries.

Table 4. Location choice analysis by source origin countries (2003-June 2017)

\begin{tabular}{|c|c|c|c|c|}
\hline \multirow[b]{2}{*}{ Independent variable } & \multicolumn{4}{|c|}{ Dependent Variables } \\
\hline & United States & UK & India & France \\
\hline \multirow[t]{2}{*}{ Big market size } & $0.443 * * *$ & $0.307 *$ & $-0.515^{* * *}$ & 0.209 \\
\hline & $(0.158)$ & $(0.161)$ & $(0.182)$ & $(0.162)$ \\
\hline \multirow[t]{2}{*}{ Small market size } & $-0.408 * *$ & -0.0834 & -0.137 & $-0.442 * *$ \\
\hline & $(0.179)$ & $(0.178)$ & $(0.19)$ & $(0.184)$ \\
\hline \multirow[t]{2}{*}{ Low income } & $-0.601 * * *$ & $-0.523^{* * *}$ & -0.0614 & -0.263 \\
\hline & $(0.184)$ & $(0.183)$ & $(0.19)$ & $(0.205)$ \\
\hline \multirow[t]{2}{*}{ Upper income } & $0.579 * * *$ & $0.312 * *$ & $-0.358 * *$ & $1.191^{* * * *}$ \\
\hline & $(0.137)$ & $(0.139)$ & $(0.159)$ & $(0.15)$ \\
\hline \multirow[t]{2}{*}{ None Top Oil \& Gas } & $-0.656 * * *$ & $-0.222 *$ & $0.572 * * *$ & $-1.257 * * *$ \\
\hline & $(0.129)$ & $(0.129)$ & $(0.143)$ & $(0.145)$ \\
\hline \multirow[t]{2}{*}{ Landlocked countries } & $-1.089 * * *$ & $-0.665^{* * * *}$ & 0.206 & $-1.531 * * *$ \\
\hline & $(0.17)$ & $(0.165)$ & $(0.17)$ & $(0.199)$ \\
\hline $\mathrm{CC}$ & Yes & Yes & Yes & Yes \\
\hline GE & Yes & Yes & Yes & Yes \\
\hline
\end{tabular}




\begin{tabular}{lcccc}
\hline PS & Yes & Yes & Yes & Yes \\
RQ & Yes & Yes & Yes & Yes \\
Other Origin Countries & Yes & Yes & Yes & Yes \\
Constant & $1.326^{* * *}$ & $1.220^{* * *}$ & $0.698^{* * *}$ & $1.411^{* * *}$ \\
& $(0.153)$ & $(0.155)$ & $(0.17)$ & $(0.156)$ \\
observation & 7,175 & 7,175 & 7,175 & 7,175 \\
\hline
\end{tabular}

(1) = Manufacturing Sector. (2) = Natural Resource Sector. Significance level: *** p<0.01, **p $<0.05, * \mathrm{p}<0.1$.

Table 4 implies that the developed countries invest more in the location with a large market size, better economic development, and location with access to the sea than the opposite. On the other hand, developing economies prefer to invest in the location with small and medium market sizes as well as less developed locations. The implication is that large market size and developed economy locations are competitive that firms from developing countries can't afford to compete with.

\section{Conclusion}

Generally, the location choice of multinational enterprises (MNEs) is thoughtfully selected and determined by the exogenous favorable business factors associated with the locations in indicating sustainable future profitability for the firm. This work analyzes these exogenous factors, which determines the MNEs' location choice in Africa. Africa, in general, is a continent with ample natural resource endowments and complex challenges. Each African country has some type of natural resources that makes impossible to classify African countries as a location with and location without natural resources. But, the type of natural resource, human capital, economic development, market size, and other economic infrastructures vary across countries in Africa; this affects the firm's investment location choices. The variables were classified according to their respective specific-attributes applying firm-level data from the Financial Times. This study exclusively uses none African MNEs data.

The study classified African countries according to their income levels, market size; landlocked countries versus countries with access to the sea. Additionally, it also classified locations as the top 20 Oil and Gas producing countries versus other countries in the continent. This classification was important because these main assets (having access to the sea vs landlocked; top 20 Oil \& Gas producing vs non-top-20 Oil \& Gas producing) can be used as a proxy for strategic assets and economic development. A number of top 20 Oil and Gas producing countries have important assets that can contribute significant development to the countries as well as make them attractive to international investors through improving the domestic living standard and enhancing the market size.

Further, the industries were also classified as a manufacturing sector, natural resource sector, and service sector according to the "North American Industry Classification System" (NAICS, 2007). In essence, the firm's engagement in the sector is one of the key determinants of location choice, for instance, the location choice of the tourism industry is totally different from the agricultural industry. The analysis also includes the origin countries, industrial sector, and subsector as a proxy for the MNEs.

Africa due to the firm's inherent characteristics and specific-location attributes. The study found that manufacturing and tertiary firms are less likely to invest in countries without sea access relative to natural resource-seeking MNEs. The paper also shows that the MNEs from developing economies are more likely to choose a location with small-medium market size and low-middle-income relative to the firms from the developed world. With these findings, this study produces critical contributions to existing location choice literature. This study introduces that the landlocked country is more likely to attract natural resource-seeking firms than manufacturing and service providing firms compared to the country with sea access. In location development prospect measured by per capita income, manufacturing MNEs preference in such location is higher than the service MNEs.

The findings of this paper reveal an important implication for the fundamental determinants of MNEs' location choice in Africa. The main implication of this study is that the underdeveloped African countries are vulnerable to natural resource exploitation due to less of other specific-location advantage attributes to offer. Landlocked countries are economically constrained, not only by lack of blue economy but overall attractiveness to international investment. Landlocked nations are more vulnerable to be exploited by MNEs because these countries desperately need FDI inflow that would help their developments and due to that economic constraint, they are forced to accept exploitative and other forms of FDI that might have insignificant development contribution to them. Besides all that, the host country's labor quality, market size, development level, and 
political stability plus a bit of a civilized culture are major forces shaping the FDI location choice in Africa.

Additionally, the host country's labor quality, market size, development level, and political stability plus a bit of a civilized culture are major forces shaping the FDI location choice in Africa. The local community should provide space for foreigners and respect the cultural, religious and appearance differences. In this study, less culturally conservative countries received the highest number and size of FDI inflow. Further, the major Oil and Gas producing African countries are a better position in attracting foreign direct investment because these big assets improve the local market economy. These locations producing major Oil and Gas in Africa attract more manufacturing investments than natural resource seeking investments.

\section{Acknowledgements}

This project was funded by the 7 Institute for Research and Development, Mogadishu, Somalia.

\section{References}

Alan, A., \& Estrin, S. (2004). The determinants of foreign direct investment into European transition economies. Journal of Comparative Economics, 32(4), 775-787. https://doi.org/10.1016/j.jce.2004.08.006

Aleksynska, M., \& Havrylchy, O. (2013). FDI from the south: The role of institutional distance and natural resources. $\quad$ European Journal of Political Economy, 29, 38-53. https://doi.org/10.1016/j.ejpoleco.2012.09.001

Assunção, S., Forte, R., \& Teixeira, A. C. (2011). Location Determinants Of FDI: A Literature Review. FEP Working Papers, 433.

Bartels, F. L., Napolitano, F., \& Tissi, E. N. (2014). FDI in Sub-Saharan Africa: A longitudinal perspective on location-specific factors (2003-2010). International Business Review, 23, 516-529. https://doi.org/10.1016/j.ibusrev.2013.08.013

Belkhodja, O. (2016). FDI Location Decision: Evidence from Firms Investing in China. International Journal of Business and Management, 11(6). https://doi.org/10.5539/ijbm.v11n6p47

Blance-Brude, F. et al. (2017). Data Collection for Infrastructure Investment Benchmarking: Objectives, Reality Check and Reporting Framework.

Blomstrom, M., \& Lipsey, R. E. (1991). Firm size and foreign operations of multinationals. Scandinavian Journal of Economics, 93(1), 101-107. https://doi.org/10.2307/3440424

Blonigen, B., Davies, R., \& Head, K. (2003). Estimating the knowledge-capital model of the multinational enterprise: Comment. American Economic Review, 93(3), 980-994. https://doi.org/10.1257/000282803322157214

Brainard, S. L. (1997). An empirical assessment of the proximity-concentration tradeoff between multinational sales and trade. American Economic Review, 87, 520-544.

Braunerhjelm, P., \& Svensson, R. (1996). Host country characteristics and agglomeration in foreign direct investment. Applied Economics, 28(7), 833-840. https://doi.org/10.1080/000368496328272

Buckley, P. J., \& Casson, M. (1976). The future of the multinational enterprise (1st ed.). London: Macmillan. https://doi.org/10.1007/978-1-349-02899-3

Buckley, P. J., Clegg, L. J., Cross, A. R., Liu, X., Voss, H., \& Zheng, P. (2007). The determinants of Chinese outward foreign direct investment. Journal of International Business Studies, 38, 499-518. https://doi.org/10.1057/palgrave.jibs.8400277

Carr, D. L., Markusen, J. R., \& Maskus, K. E. (2001). Estimating the knowledge-capital model of the multinational enterprise. American Economic Review, 91, 693-708. https://doi.org/10.1257/aer.91.3.693

Chanegriha, M., Chris, S. Ch., \& Tsoukis, Ch. (2017). Identifying the robust economic, geographical and political determinants of FDI: An Extreme Bounds Analysis. Empir. Econ., 52, 759-776. https://doi.org/10.1007/s00181-016-1097-1

Coughlin, C. C., Joseph, V. T., \& Vachira, A. (1991). State characteristics and the location of forign direct investment within the United States. Review of Economics and Statistics, 73, 675-683. https://doi.org/10.2307/2109406

Deng, P. (2004). Outward investment by Chinese MNCs: Motivations and implications. Business Horizons, 47(3), 8-16. https://doi.org/10.1016/S0007-6813(04)00023-0 
Du, J., Lu, Y., \& Tao, Z. (2007). FDI Location Choice in China: Agglomeration vs. Institutions. International Journal of Finance \& Economics, 13(1), 92-107. https://doi.org/10.1002/ijfe.348

Du, J., Lu, Y., \& Tao, Z. (2008). Economic Institutions and FDI Location Choice: Evidence from US Multinationals in China. Journal of Comparative Economics, 36(3), 412-429. https://doi.org/10.1016/j.jce.2008.04.004

Dunning, J. (1973). The Determinants of International Production. Oxford Economic Papers, 25(3), 289-336. https://doi.org/10.1093/oxfordjournals.oep.a041261

Dunning, J. (1981). International Production and the Multinational Enterprise. London, UK.

Dunning, J. (1987). The Eclectic Paradigm of International Production: A Restatement and Some Possible Extensions.

Dunning, J. H. (1979). The Eclectic Paradigm of International Production: A Restatement and Some Possible Extension.

Dunning, J. H. (1981). International Production and the Multinational Enterprise. London, UK: Allen \& Unwin.

Dunning, J., \& Narula, R. (1993). Transpacific Foreign Direct Investment and The Investment Development Path.

Faeth, I. (2009). Determinants of Foreign Direct Investment - A Tale of Nine Theoretical Models. https://doi.org/10.1111/j.1467-6419.2008.00560.x

Fonseca, M. R., Mendonça, A., \& Passos, J. (2016). The Paradigm of The Investment Development Path: Does It Holds for Portugal? Evidence for The Period 1990-2011. Working Paper Cesa Csg 139.

Javorcik, B. S. (2004). The composition of foreign direct investment and protection of intellectual property rights: Evidence from transition economies. European Economics Review, 48, 39-62. https://doi.org/10.1016/S0014-2921(02)00257-X

Jing-Lin, D. (2012). Firm heterogeneity and location choice of Chinese Multinational Enterprises (MNEs). Journal of World Business, 47, 64-72. https://doi.org/10.1016/j.jwb.2010.10.021

Josep, M., Maite, A., \& Vicente, O. (2015). Location choice of Spanish multinational firms in developing and transition economies. Journal of Business Economics and Management, 18(2), 319-339. https://doi.org/10.3846/16111699.2015.1013980

Kang, Y. (2018). Regulatory institutions, natural resource endowment and location choice of emerging-market FDI: A dynamic panel data analysis. Journal of Multinational Financial Management, 45, 1-14. https://doi.org/10.1016/j.mulfin.2018.04.003

Kang, Y., \& Jiang, F. (2010). FDI Location Choice of Chinese Multinationals in East and Southeast Asia: Traditional Economic Factors and Institutional Perspective.

Li, X., Hou, K., \& Lu, M. W. (2008). An Empirical Study of Foreign Direct Investment Location in Eastern China. The Chinese Economy, 41(6), 75-98. https://doi.org/10.2753/CES1097-1475410604

Lin, F. J. (2010). The determinants of foreign direct investment in China: The case of Taiwanese firms in the IT industry. Journal of Business Research, 63(5), 479-485. https://doi.org/10.1016/j.jbusres.2009.04.005

Liu, X., Lovely, E. M., \& Ondrich, J. (2010). The Location Decisions of Foreign Investors in China: Untangling The Effect Of Wages Using A Control Function Approach. The Review of Economics \& Statistics, 92(1), 160-166. https://doi.org/10.1162/rest.2009.11350

Markusen \& Venables. (1999). Foreign Direct Investment as a Catalyst for Industrial Development. European Economic Review, 43, 335-356. https://doi.org/10.1016/S0014-2921(98)00048-8

Na, Lv., \& Lightfoot, W. S. (2006). Determinants of foreign direct investment at the regional level in China. Journal of Technology Management in China, 1(3), 262-278. https://doi.org/10.1108/17468770610704930

Nachum, L., Zaheer, S., \& Gross, Sh. (2008). Does It Matter Where Countries Are? Proximity to Knowledge, Markets and Resources, And MNE Location Choices. Management Science, 54(7), 1252-1265. https://doi.org/10.1287/mnsc. 1080.0865

North American Industry. (2007). Classification System (NAICS) - Canada. Catalogue no. 12-501-XIE.

OECD. (2008). Organization for Economic Co-Operation and Development: OECD Benchmark, Definition of Foreign Direct Investment (4th ed., p. 14). 
Okafora, G., Piesseb, J., \& Webster, A. (2015). The motives for inward FDI into Sub-Saharan African countries. Journal of Policy Modeling, 37, 875-890. https://doi.org/10.1016/j.jpolmod.2015.07.003

Ovidiu, S. (2011). The Investment Development Path - Literature Review.

Perkins, J. (2004). The Confessions of An Economic Hit Man Book (pp. 1-30).

Ramasamy, B., Yeung, M., \& Laforet, S. (2012). China's outward foreign direct investment: Location choice and firm ownership. Journal of World Business, 47(1), 17-25. https://doi.org/10.1016/j.jwb.2010.10.016

Rjoub, H. et al. (2017). Financial Reforms and Determinants of FDI: Evidence from Landlocked Countries in Sub-Saharan Africa. https://doi.org/10.3390/economies5010001

Saidi, Y., Ochi, A., \& Ghadri, H. (2013). Governance and FDI Attractiveness: Some Evidence from Developing and Developed Countries. Global Journal of Management and Business Research Finance.

Sethi, D., Guisinger, S. E., Phelan, S. E., \& Berg, D. M. (2003). Trends in Foreign Direct Investment Flows: A Theoretical and Empirical Analysis. Journal of International Business Studies, 34(4), 315-326. https://doi.org/10.1057/palgrave.jibs.8400034

Sridhar, S. K., \& Wan, G. (2010). Firm Location Choice in Cities: Evidence from China and India. China Economic Review. https://doi.org/10.1016/j.chieco.2009.11.003

Urata, S., \& Kawai, H. (2000). The determinants of the location of foreign direct investment by Japanese small and medium-sized enterprises. Small Business Economics, 15(2), 79-103. https://doi.org/10.1023/A:1008173912813

Vijayakumar, N., Sridharan, P., \& Rao, K. C. S. (2010). Determinants of FDI in BRICS countries: A panel analysis. International Journal of Business Science and Applied Management, 5(3), 1-13.

Wheeler, D., \& Mody, A (1992). International Investment Location Decision - The Case of United-States Firms. Journal of International Economics, 33(1-2), 57-76. https://doi.org/10.1016/0022-1996(92)90050-T

Yao, S., Wang, P., Zhang, J., \& Ou, J. (2016). Dynamic relationship between China's inward and outward foreign direct investments. China Economic Review, 40. https://doi.org/10.1016/j.chieco.2016.05.005

\section{Appendix}

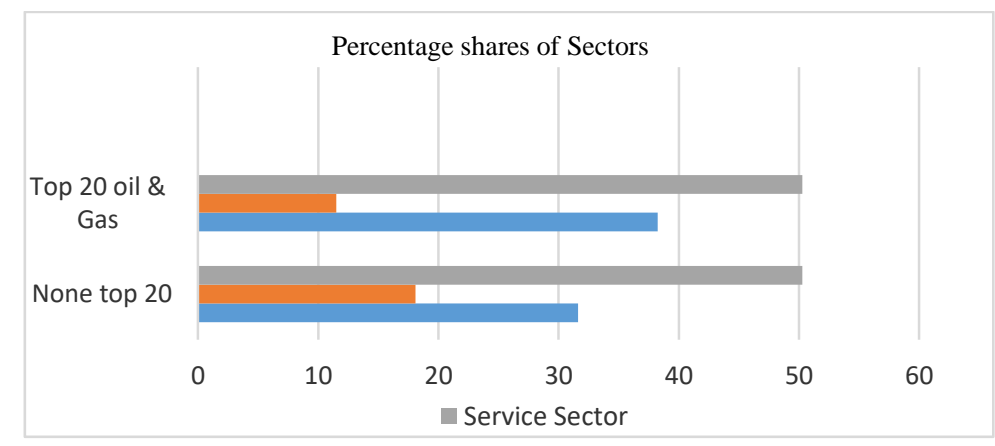

Figure 1. Top 20 oil \& gas producing countries and other countries in Africa (2003-June 2017)

Source: author's computation.

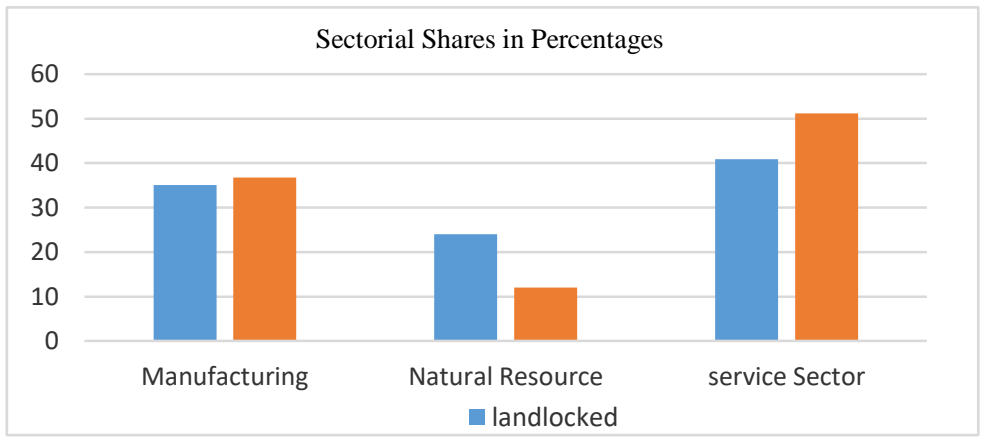

Figure 2. Sectors in the countries have access to sea and landlocked countries (2003-June 2017) 


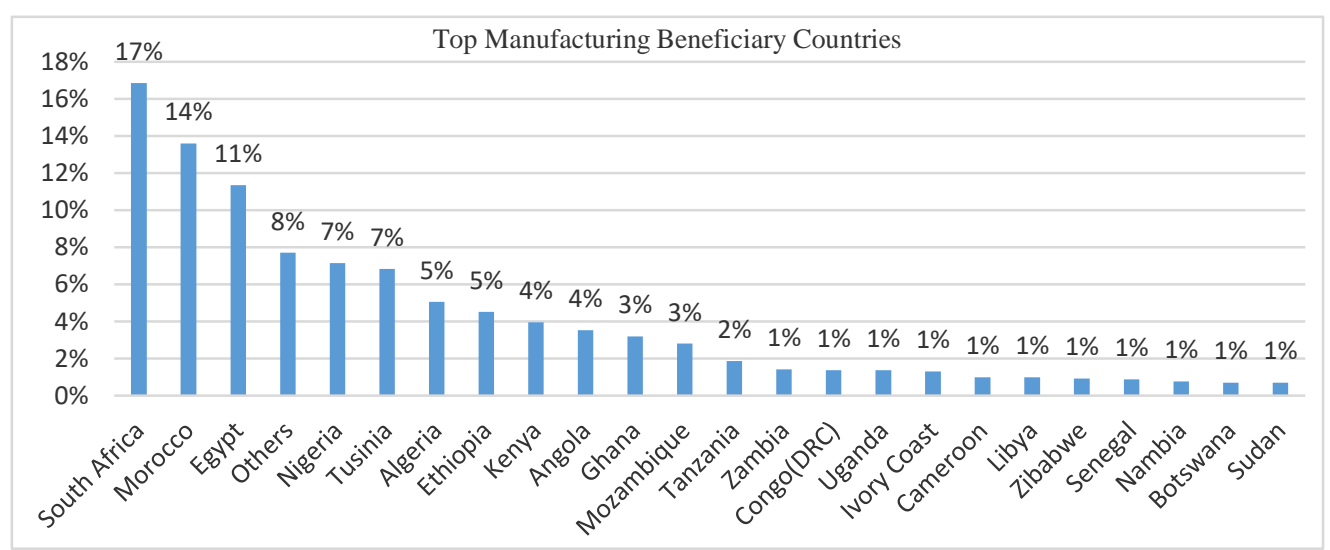

Figure 3. Top manufacturing projects beneficiary countries (2003-June 2017)

Source: author's computation.

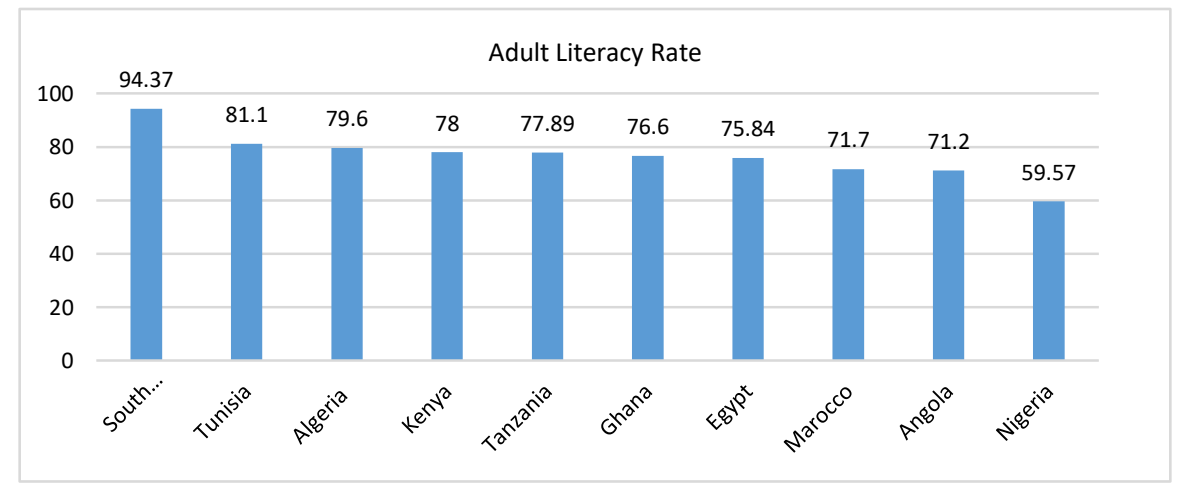

Figure 4. Adult literacy rate of top 10 locations chosen as an investment location

Source: UNESCO, 2015.

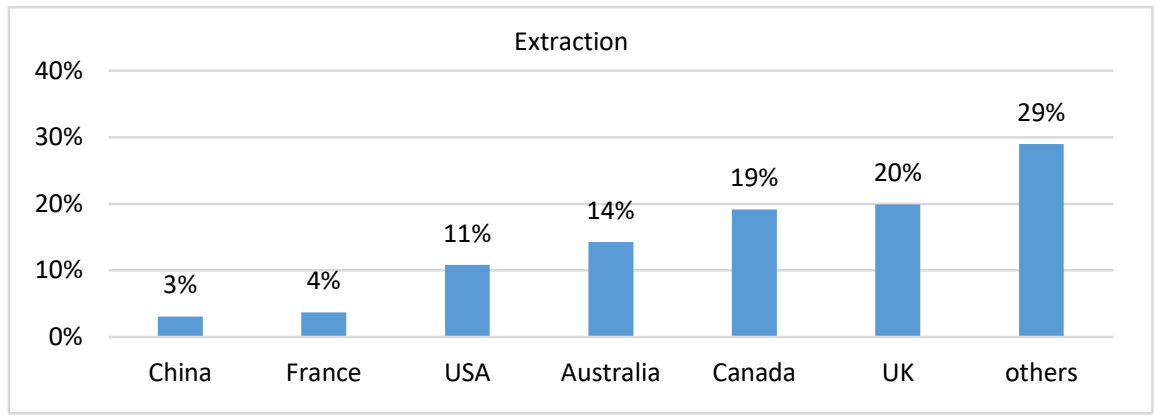

Figure 5. Natural resource extraction shares among investor countries

Source: author's computation.

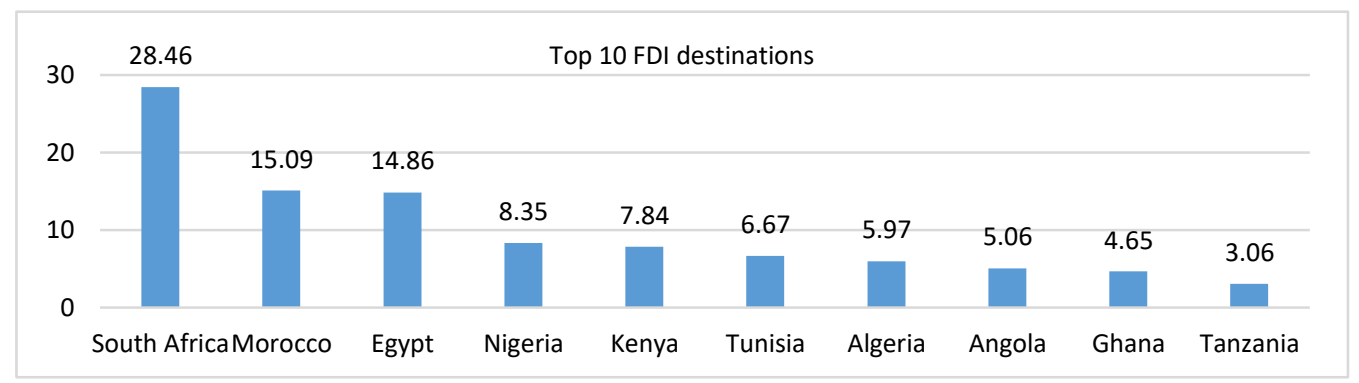

Figure 6. Top ten selected locations as investment destinations in Africa (2003-June 2017)

Source: author's computation. 


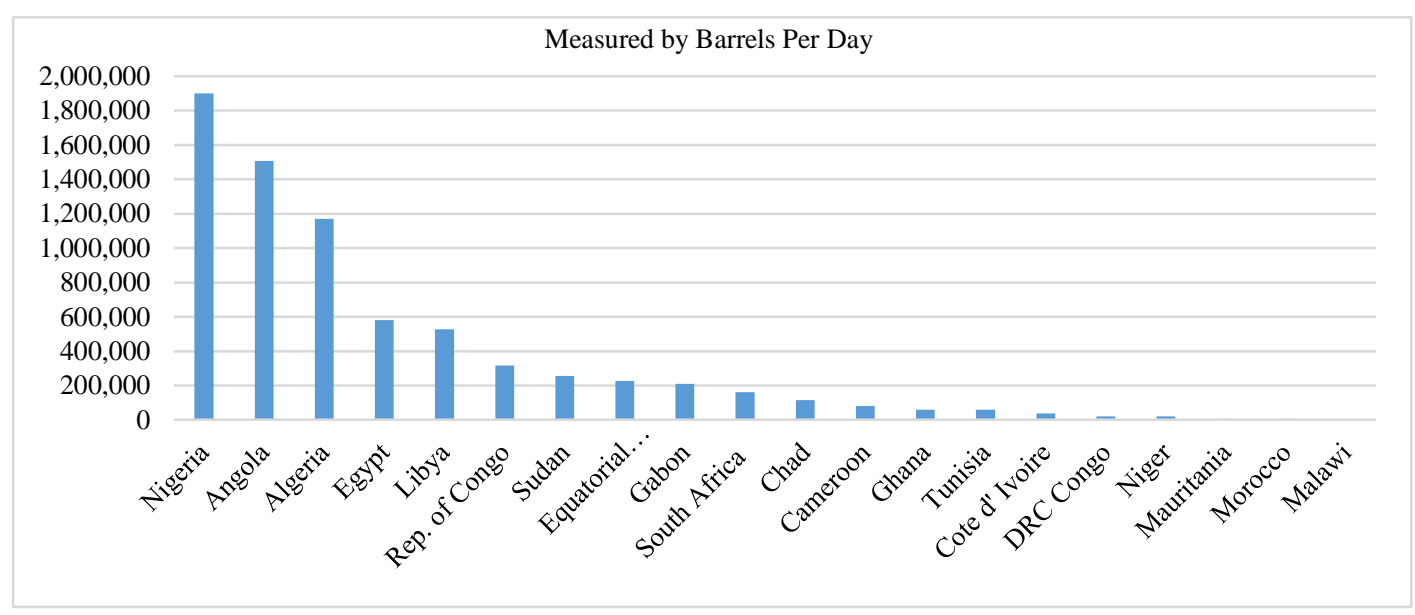

Figure 7. The top 20 oil \& gas producing countries in Africa measured by Barrels

Source: author's computation.

Table A1. Correlations between variables (Pearson coefficient)

\begin{tabular}{llllllll}
\hline & 1 & 2 & 3 & 4 & 5 & 6 & 7 \\
\hline 1.Markets & 1.0000 & & & & & & \\
2.Income & -0.6325 & 1.0000 & & & & & \\
3.Ports & -0.4745 & 0.4636 & 1.0000 & & & & \\
4.Oil \& Gas & 0.7239 & -0.6382 & -0.4879 & 1.0000 & & & \\
5.Origin & -0.0646 & 0.0321 & 0.0362 & -0.0254 & 1.0000 & & \\
6.Sectors & 0.0459 & -0.0156 & 0.0275 & 0.0311 & 0.0783 & 1.0000 & 1.0000 \\
7.Firm Activity & -0.0308 & -0.0038 & -0.0039 & -0.0129 & -0.0537 & -0.4814 & \\
\hline
\end{tabular}

Source: author's computation.

Note. This table shows that the top twenty (20) Oil and Gas producing nations are the countries with large market size (measured by GDP). According this table there are positive relationship between producing oil and gas and market size. The countries which produce oil and natural gas have important source of income generation that contribute significant amount to the national gross domestic products.

\section{Table A2. Relative risk ratio for multinomial estimation results}

\begin{tabular}{lcc}
\hline & Dependent Variables (Firm's location Choice) & \\
\hline Markets & (Manufacturing) & (Resource) \\
\hline Large size & $1.027^{*}$ & $0.825^{*}$ \\
& $(0.0727)$ & $(0.087)$ \\
Small Size & $0.731^{*}$ & 1.508 \\
& $(0.0733)$ & $(0.196)$ \\
Low income & $1.026^{*}$ & 1.294 \\
& $(0.099)$ & $(0.150)$ \\
Upper income & $1.065^{*}$ & 0.824 \\
& $(0.086)$ & $(0.086)$ \\
None Top 20 Gas \& Oil Locations & $0.9437^{*}$ & $1.010^{*}$ \\
& $(0.0614)$ & $(0.0896)$ \\
Landlocked Locations & 1.297 & 1.365 \\
& $(0.129)$ & $(0.163)$ \\
Government Effectiveness & yes & yes \\
Voice \& Accountability & yes & yes \\
Corruption Controls & yes & yes \\
Regulatory Quality & yes & yes \\
Political Stability & yes & yes \\
Rule of Law & yes & yes \\
Observations & 7,175 & 7,175 \\
\hline
\end{tabular}

Significance code: $* * * \mathrm{p}<0.01, * * \mathrm{p}<0.05, * \mathrm{p}<0.1$. 


\section{Table A3. Definitions of control variables}

Political Stability and Absence of Violence/Terrorism. This measures perceptions of the likelihood of political instability and/or politically-motivated violence, including terrorism.

Government Effectiveness. Reflects perceptions of the quality of public services, the quality of the civil service and the degree of its independence from political pressures, the quality of policy formulation and implementation, and the credibility of the government's commitment to such policies.

Regulatory Quality. Reflects perceptions of the ability of the government to formulate and implement sound policies and regulations that permit and promote private sector development.

Control of Corruption. Reflects perceptions of the extent to which public power is exercised for private gain, including both petty and grand forms of corruption, as well as "capture" of the state by elites and private interests.

Source: World Development Indicators, World Bank, 2020.

\section{Notes}

Note 1. Demand-oriented location choice occurs when the international companies try to fulfill unsatisfied needs in the local markets of the hosting country (business opportunities). On the other hand, supply-oriented location occurs when the multinational firms seek cheaper factors of production (e.g. raw materials, labor and distribution strategy), Dunning (1973). Both orientations can also lead the multinational enterprises to penetrates international markets and compete with local firms in the markets exercising their comparative advantages. Besides, our studies showed that the market size of FDI hosting countries is important for inward FDI attractiveness. Very influential factors when it comes to location choice include market size.

Note 2. The governance indicator data is lagged one year because MNEs examine the location quality before deciding to go and invest in there.

Note 3. With chronological order, the top 20 Gas \& Oil producing countries are: Nigeria, Angola, Algeria, Egypt, Libya, Rep. of Congo, Sudan, Equatorial Guinea, Gabon, South Africa, Chad, Cameroon, Ghana, Tunisia, Cote d' Ivoire, DRC Congo, Niger, Mauritania, Morocco, and Malawi, respectively.

The landlocked countries in Africa are: Botswana, Burkina Faso, Burundi, Central African Republic, Chad, Ethiopia, Lesotho, Malawi, Mali, Niger, Rwanda, South Sudan, Swaziland, Uganda, Zambia, and Zimbabwe.

\section{Copyrights}

Copyright for this article is retained by the author(s), with first publication rights granted to the journal.

This is an open-access article distributed under the terms and conditions of the Creative Commons Attribution license (http://creativecommons.org/licenses/by/4.0/). 